\title{
FOSSIL BACTERIAL FORMS IN EARLY PROTEROZOIC DOLOMITE AT KIIHTELYSVAARA IN EASTERN FINLAND
}

\author{
RISTO TYNNI and OLLI SARAPÄÄ
}

\begin{abstract}
TYNNI, RISTO and SARAPÄÄ, OLLI 1987: Fossil bacterial forms in Early Proterozoic dolomite at Kiihtelysvaara in eastern Finland. Bull. Geol. Soc. Finland 59, Part 2, 81-95.

The study deals with the bacterial type discovered in a Jatulian deposit at Kiihtelysvaara. The morphology of the microbic fossil, when compared with current forms, suggests that it is an early sulphur bacterium, named Hyypiana jatulica.

The deposit is part of the Marine Jatulian dated at c. $2000 \mathrm{Ma}$. The fossile type occurs in chert nodules within the dolomite.
\end{abstract}

Key words: bacteria, Hyypiana jatulica, chert, concretions, dolostone, Proterozoic, Hyypiä, Kiihtelysvaara, Finland.

Risto Tynni and Olli Sarapää: Geological Survey of Finland, SF-02150, Espoo, Finland.

\section{Location and geological setting}

The village of Hyypiä in the municipality of Kiihtelysvaara is situated about $40 \mathrm{~km}$ southeast of Joensuu, eastern Finland (Fig. 1). The geology of the Hyypiä area has been described by Nykänen (1971a) and by Pekkarinen (1979). In the course of studies of the graphite deposit of Hyypiä by the Geological Survey of Finland in the 1980s undertaken some samples were selected for microfossil study.

In the Hyypiä area the Archaean Presvecokarelidic basement complex consists mainly of gneissose granodiorites to quartzdiorites, which in eastern Finland date back 2600-2800 Ma (Pekkarinen 1979; Simonen 1980). The Proterozoic Karelidic formations, which rest unconformably on the basement, are divided into three groups: the Sariolian (2500-2300 Ma), the Jatulian (2200-2000 Ma) and the Kalevian (about $2000 \mathrm{Ma}$; Meriläinen 1980).
The Sariolian Group, which is about $120 \mathrm{~m}$ thick (Fig. 2), consists of basal arkosite, conglomerate and arkosite (called the Arkosite Formation by Pekkarinen 1979).

The Sariolan metasediments are overlain unconformably by the Jatulian Group with regolith development at the contact (Pekkarinen 1979). The lower part of the Jatulian is composed of two quartzite formations separated by the Volcanite Formation (Figs. 1 and 2). The Lower quartzite Formation is $200-300 \mathrm{~m}$ thick and consists of sericite quartzite and orthoquartzite with minor quartz conglomerate interbeds. The Upper quartzite Formation, which is about $100 \mathrm{~m}$ thick, is composed of impure quartzite with abundant conglomerate interbeds and a few metavolcanite and clay slate intercalations.

The Jatulian quartzites are overlain by Marine Jatulian dolomites and carbonaceous slates, which are not exposed in the study area but have been intersected by diamond drilling. A complete 


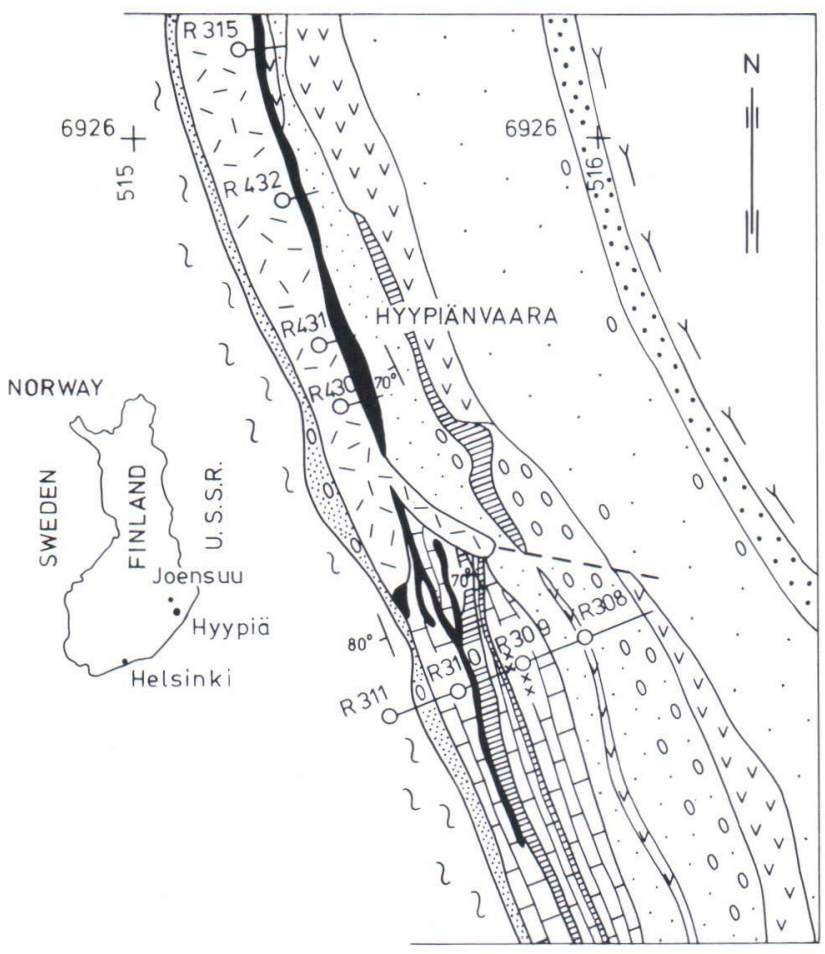

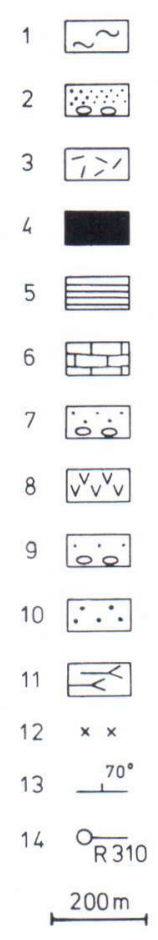

Fig. 1. Geological map of the Kiihtelysvaara Hyypiä area. Kalevian: 1 mica schist; 2 turbidite conglomerate and quartzite. Jatulian; 3 metadiabase; 4 carbon-rich slate; 5 carbonaceous slate and phyllite; 6 dolomite; 7 upper quartzite and conglomerate; 8 metavolcanite; 9 lower quartzite and conglomerate. Sariolian: 10 arkosite. Prekarelidic: 11 granodiorite and quartz diorite. 12 chert nodules; 13 bedding; 14 drill hole. sequence of the Marine Jatulian rocks has been described by Pekkarinen (1979). The Marine Jatulian begins with dolomite that contains some thin quartzite, clay slate and nodular chert layers overlain by metavolcanite (the Dolomite-Volcanite Formation, Fig. 2) and succeeded by compact haematite rock and quartzite (the Haematite rock-Quartzite Formation). In the upper part of the Marine Jatulian, laminated dolomites and carbonaceous slates with some carbon-rich layers (about $30 \% \mathrm{C}$, from 1 to $20 \mathrm{~m}$ thick) occur as alternating layers (the DolomiteCarbonaceous slate-Volcanite Formation). The Marine Jatulian rocks are from 10 to $240 \mathrm{~m}$ thick in Hyypiä. The Karelian formations are cut by metadiabases, and locally a coarse sill-like gabbroic metadiabase occurs between the Jatulian and the overlying Kalevian rocks (Fig. 1). Radiometric age determinations of zircon from the metadiabase cutting the Lower quartzite Formation at Hyypiä gives $2112 \mathrm{Ma}$ (U-Pb age by Sakko in Pekkarinen 1979). The age of the Marine Jatulian rocks is approximately $2100-2000 \mathrm{Ma}$ on the basis of ages determined elsewhere in Finland (Pekkarinen 1979; Meriläinen 1980).

The Kalevian Group, which rests unconformably on the Marine Jatulian rocks, begins with a thin conglomerate layer. This is followed by graded-bedded quartzite overlain by staurolite mica schists (Pekkarinen 1979). The thickness of the Kalevian exceeds $1000 \mathrm{~m}$.

The Sariolian arkoses have been interpreted as fluvial deposits (Ojakangas 1965; Pekkarinen 1979), whereas the Jatulian quartzites deposited during a marine transgression in a near-shore environment and the Marine Jatulian dolomites and carbonaceous slates represent ancient shallow marine sediments.

The Kalevian rocks have been interpreted as deeper marine accumulations (Nykänen 1971b; Pekkarinen 1979). 


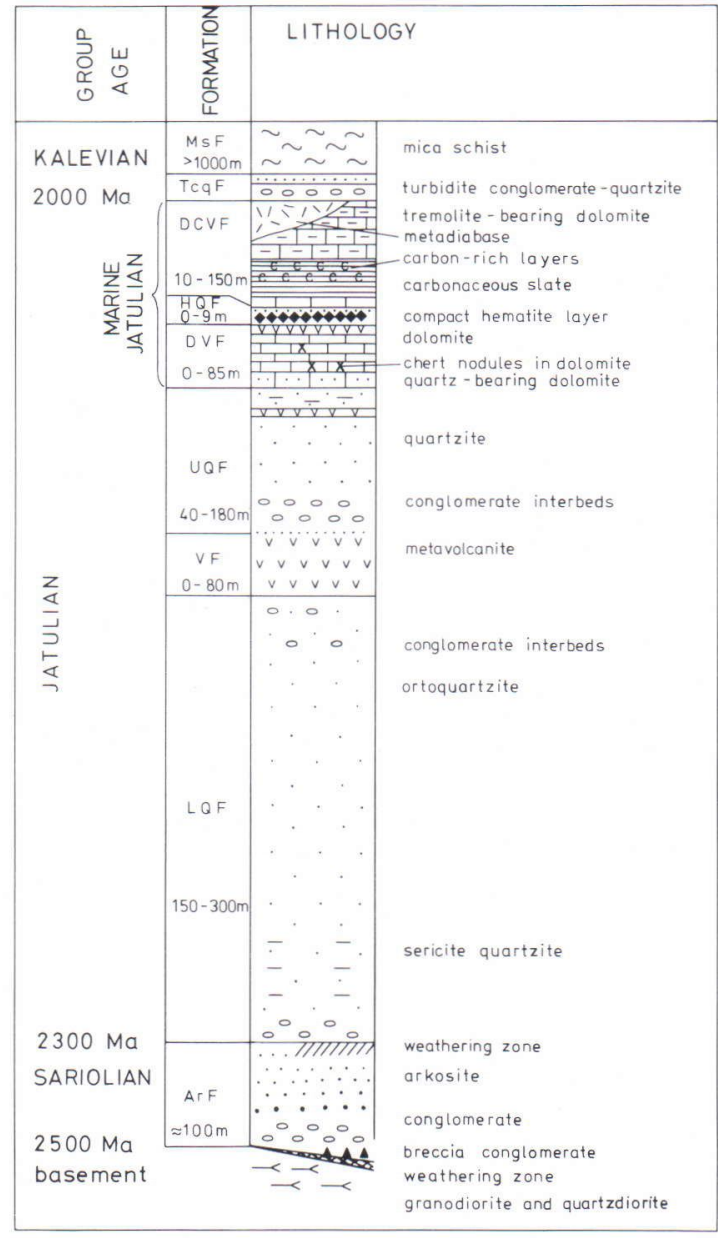

Fig. 2. Stratigraphy of the Hyypiä area. Column modified after Pekkarinen (1979). Symbols of formations: MsF = Mica schist Formation; TcqF = Turbiditeconglomerate-quartzite Formation; DCVF = Dolomite-Carbonaceous slate-Volcanite Formation; HQF = Haematite rock-Quartzite Formation; DVF = Dolomite-Volcanite Formation; $\mathrm{UQF}=$ Upper quartzite Formation; VF = Volcanite Formation; LQF = Lower quartzite Formation; $\mathrm{ArF}=$ Arkosite Formation.

The Karelidic formations were deformed and metamorphosed during the Svekokarelidic orogeny about 1900 to 1950 Ma ago (Simonen 1980). In the Hyypiä area the degree of metamorphism corresponds to the low-grade metamorphism of Winkler (1979).

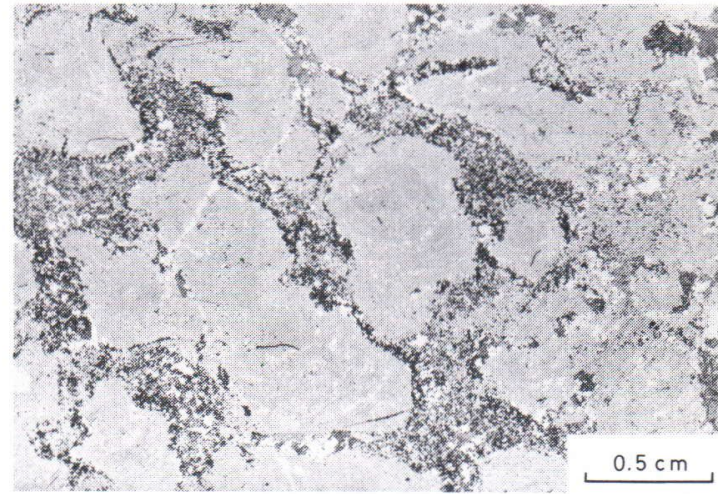

Fig. 3. Chert nodules in carbonate and quartz matrix. One nicol. Photo by $\mathbf{J}$. Väätäinen.

\section{Chert nodules in dolomite}

Nodular chert occurs in the Marine Jatulian dolomites as thin layers from a few decimetres to a couple of metres thick.

Microfossil-bearing chert nodules were found in a sample from drill hole 310 , at a depth of $185.50 \mathrm{~m}$. Stratigraphically the sample lies $65 \mathrm{~m}$ below the massive haematite rock (Fig. 2).

Elongated parallel to the bedding, the chert nodules are irregularly shaped, structureless and rounded. They range in size from 0.5 to $3 \mathrm{~cm}$ and are very tightly packed (Fig. 3). The nodules, which account for about $80 \%$ of the rock, consist mainly of microcrystalline quartz (ø $0.01-0.05 \mathrm{~mm}$ ). The matrix between the nodules contains calcite, dolomite and quartz. The accessory minerals are biotite, sericite and haematite.

In thin section the tubelike bacterial colonies are colourless or a light brownish colour and occur as inclusions in cherty quartz. They will be described in greater detail later in this paper.

The genesis of chert nodules in carbonate rocks is not fully understood but they probably originated epigenetically during early stages of diagenesis (Pettijohn 1975).

Of interest in this context is the fact that a search made for microfossils from carbon-rich slate failed even though the isotopic composition 
of carbon, $-19.8 \delta^{13} \mathrm{C}(\% 0)$ (analysis by Eric Welin) refers to biogenic carbon.

\section{Introduction to micropalaeontological studies}

The sediment formation deposited during the Marine Jatulian stage about $2.1 \mathrm{Ma}$ ago at a place that is now the site of the village of Hyypiä in Kiihtelysvaara. It is largely metamorphosed into dolomite and carbonaceous slate, and conditions have not favoured the preservation of the microfossils deposited. Structures interpreted as organogenic have previously been described from the Marine Jatulian dolomite at Kiihtelysvaara. They are flattened vesicles, c. $30 \mu$ in diameter, with a punctate surface (Tynni 1971). This type was not encountered in the present study. From farther east, in the territory of the USSR, spheroidal microfossils have been described from Marine Jatulian formations, e.g. from shungite (Timofeev 1969; Vologdin 1970). Stromatolitic structures of the same age have also been described from northern Finland (Härme and Perttunen 1963) and Carelozoon jatuliticum from Soviet Karelia (Metzger 1924).

In the present study, not only did we have a larger number of samples at our disposal than previously but they also encompassed a wider variation in the sedimentary rocks. The new study also deals with carbonatic chert and chert nodules, which are favourable environments for the survival of microfossils. The study showed that the chert nodules contain abundant spiral chain colonies of small dots, $<1 \mu$ in diameter, or more dense dot swarms inside a cylindrical sheath closed at one end. They represent a bacterial type that does not originate from the recent or postglacial bacterial population, because the depth of the occurrence, $185.5 \mathrm{~m}$, and the dense structure of the rock eliminate the possibility of contamination. The form also occurs in thin sections embedded in rock material and thus has not been able to get into the samples during preparation.

\section{The bacterial type discovered from the Jatulian deposit in Kiihtelysvaara}

Hyypiana jatulica n. gen., species R. Tynni Fig. 4: A, B, C, D, Fig. 5: A-L, Fig. 6.

Description: The most characteristic form is a cylindrical sheath. At one end it is often rounded but at the other end it is ruptured in a serrated fashion. Inside the sheath there are spiral dot filaments or dot swarms. As a rule the sheath is 15-40 $\mu$ long, averaging $20 \mu$. The width varies
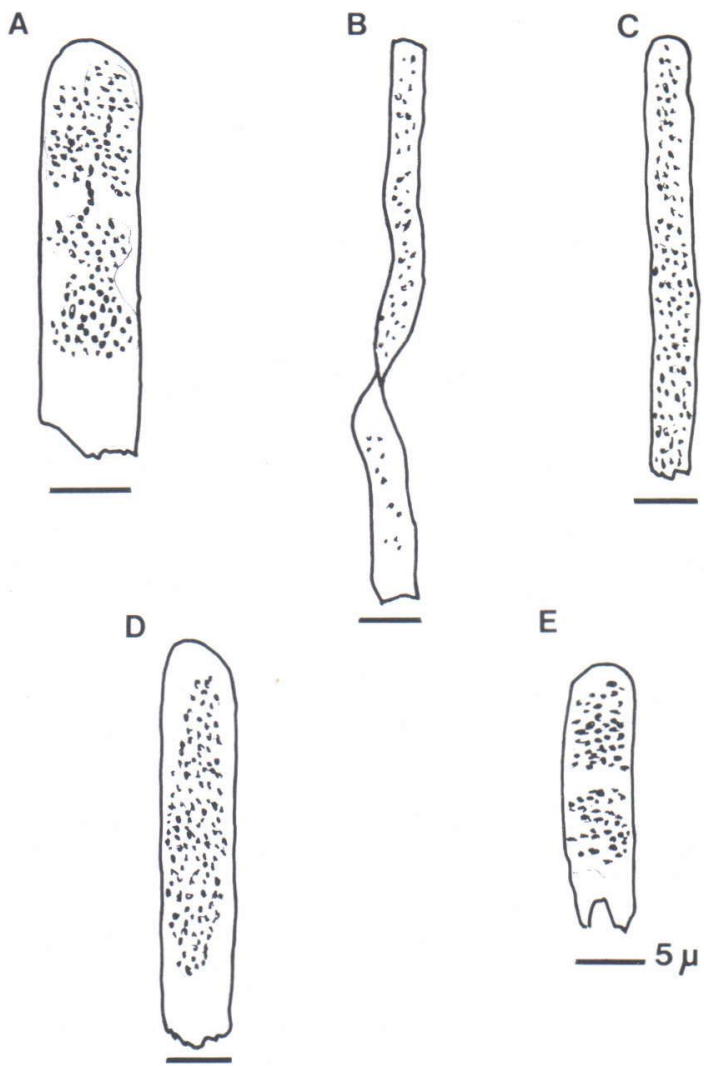

E

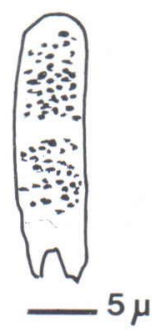

Figs. 4 A-E. Hyypiana jatulica n. ge., n. spec,, a selection of various types. A Holotype, cf. Fig. 5 L. Two thickenings of dot swarms are visible in the sheath and a spiral punctate filament; B. Possibly the same bacterial species, but a narrower and longer noncrystallized form; C. A characteristic sheath rounded at one end and ruptured at the other. Inside the sheath there are dot colonies varying in density; E. An ensheathed form within which the dot colonies are divided into two groups. The scale bar $5 \mu$ long. 

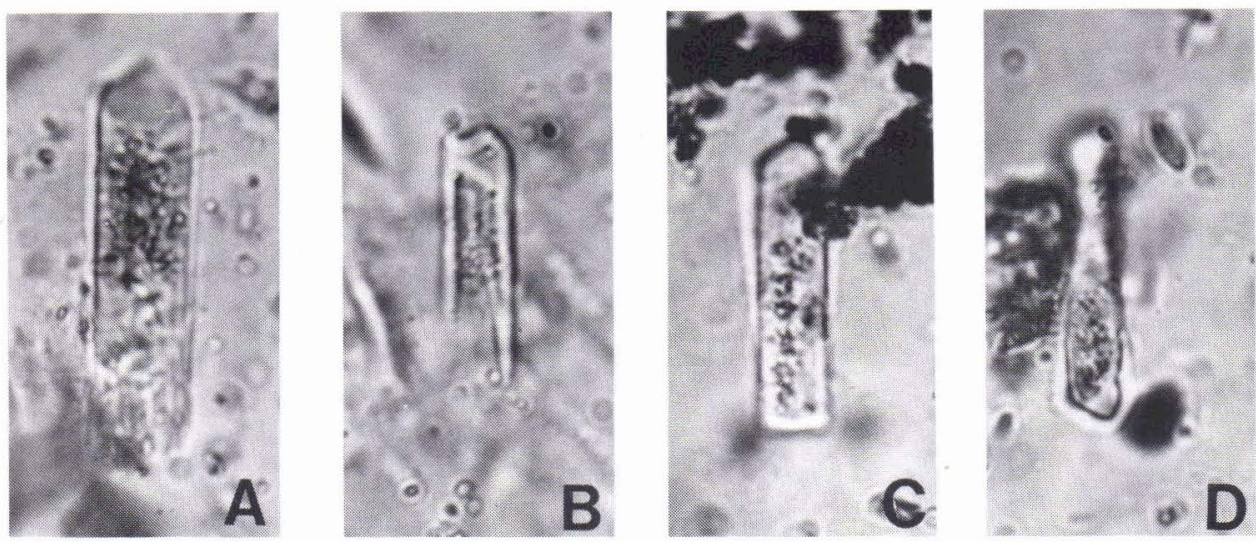

\section{$10 \mu \mathrm{m}$}
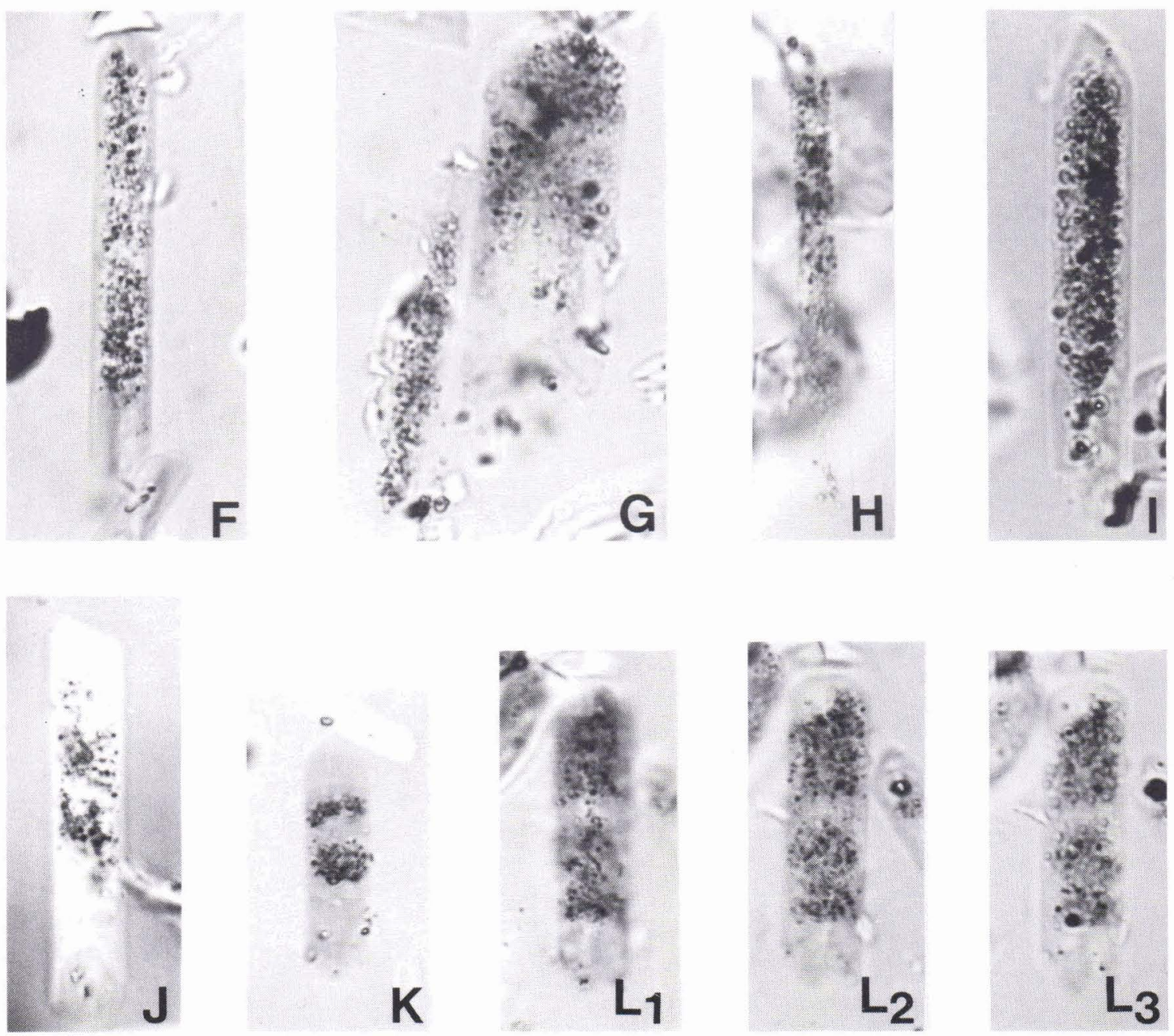

Figs. 5 A-L. Hyypiana jatulica, a selection of different types as shown by photographs. Figs. A-D photographed from thin sections; Figs. E- L from maceration residue. Fig. $\mathrm{L}_{1-3}$ is the holotype, in three focal planes, the others are paratypes. 
from 3 to $12 \mu$, averaging $5 \mu$. In thin section and etching residue the sheath is pale and transparent. The internal dots are c. $0.4 \mu$ in diameter. Examples of the dot groups are seen in Figs. 4 and 5 , and in higher magnification in Fig. 6. The spiral coils of the dot filaments are clearly shown, particularly in Figs. $5 \mathrm{~F}$ and 6 . The closely packed dot filaments occur in dense swarms as shown in Fig. $5 \mathrm{~J}$. A sheath may contain successive thickenings of dot swarms. The intervals poor in dots between the swarms may correspond to the dividing phase of a cell. Figs. $5 \mathrm{~K}$ and $\mathrm{L}$ show two successive thickenings.

Etymology: Hyypiä, site of find, a village in Kiihtelysvaara, jatulica - the stratigraphic unit of the deposit.

Holotype: Fig. 4 A, Fig. 5 L, GSF prep. 760, 40.5/106.0.

Site of find: Village of Hyypiä, Kiihtelysvaara, chert nodule in dolomite in Viistola core No. 310 at $185.50 \mathrm{~m}$.

Remarks: Some of the sheaths are crystalline in appearance with straight walls, but some are relatively long, like hollow thread in the middle and with walls that are not completely straight (Figs. $5 \mathrm{E}, \mathrm{H}$ ). In a single case, in Fig. 4 B, a threadlike form c. $50 \mu$ long and $3 \mu$ wide is clearly visible. The dots are similar to those in other sheaths. The crystalline morphology can possibly be attributed to postdepositional diagenesis associated with the rapid crystallization of carbonate in the sheath. Since the sheath has even survived $\mathrm{HCl}$ and $\mathrm{HF}$ treatment and is transparent it is probably organic in origin. Note that in thin section abundant adjacent dot rows and loose dots are seen outside the sheaths. They may well correspond to intrasheathal portions of disintegrated formations.

Discussion: Organisms, such as blue-green algae or cyanobacteria and bacteria proper, that lived on photosynthesis and chemosynthesis were already in existence in the Proterozoic Era when the formation was deposited. They derived their energy from the elements that underwent redox reactions. Bacteria that obtained their energy jointly from photosynthesis and autotrophy also had an early existence.

The morphology of the microfossil of Kiihtelysvaara is indicative of a sulphur bacterium. The Beggiatoa sulphur bacteria of the order Chlamydobacteriales, which belong to the present-day ensheathed bacteria, resemble the relatively long form of Kiihtelysvaara (Fig. $5 \mathrm{H}$ ). Beggiatoa filaments with the internal sulphur sphere groups have been described by La Rivière (1966) and Stanier et al. (1976, p. 570). Thiothrix also produces intrasheathal sulphur sphere colonies, and one end of the sheath is attached to the base as in the former type. The ruptured end of the sheath of the Kiihtelysvaara form may indicate a disturbance in crystallization or detachment of the sheath from the base on which it was growing.

Autotrophes of the family Beggiatoceae oxidize mainly sulphides into sulphur and then collect the sulphur into their cells, which are markedly larger than those of other bacteria. Nowadays Beggiatoa bacteria live only in environments with low concentrations of $\mathrm{O}_{2}$ and $\mathrm{H}_{2} \mathrm{~S}$ (La Rivière 1966). According to Stanier et al. (1976), the Beggiatoa-Thiothrix groups is typical of certain sulphide-rich environments, and these bacteria often contain sulphur as fixed inclusions.

Comparison with the present-day Beggiatoa bacterium is wellmotivated for morphological reasons and because of the results of previous studies. Sulphur isotope studies and the occurrence of iron oxides show that sulphur was oxidized under continental conditions $2.2 \times 10^{9}$ years ago (Hattori et al. 1983).

Awramik, Schopf and Walter (1983) have described ribbonlike fossil bacteria from the c. 3500 Ma old Warroona Group in western Australia. Warrawoonella radia, as a potential microfossil, has been compared with the current rosette-forming bacterial colonies Thiothrix and Leucothrix.

Warrawoonella differs from the Kiihtelysvaara form in that the non-septate filaments $(2-30)$ 
Fig. 6. The figure is an enlargement of Fig. $5 \mathrm{~F}$. The size of the dots and the spiral-like grouping visible.

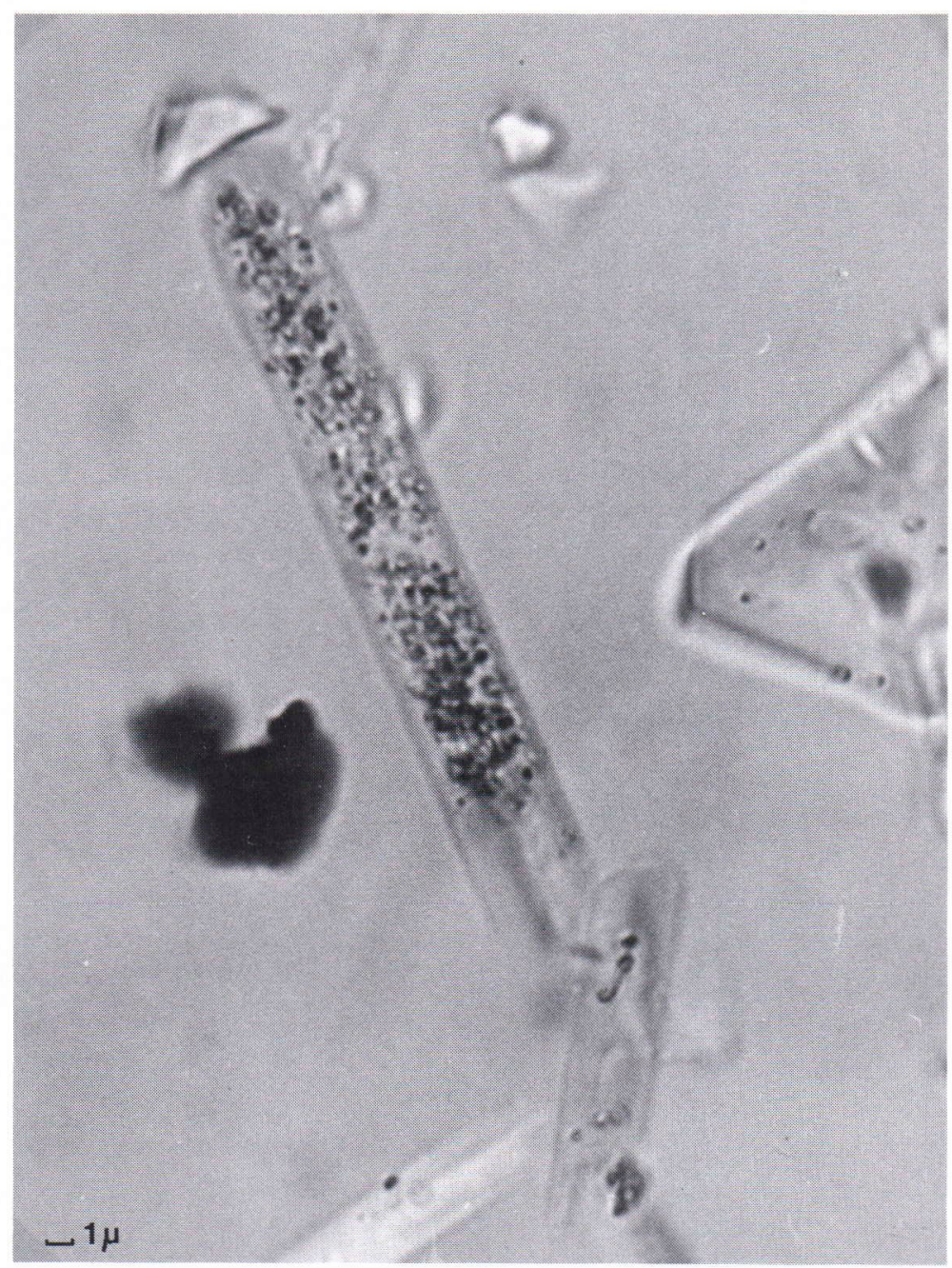

occur as an irregular radial bunch attached to a basal point and form a group shaped like a half sphere. The filaments are $0.5-0.75 \mu$ in diameter and $135 \mu$ in length. They are generally covered with minerals (iron or manganese oxides) and ruptured into rod-like segments.

A SEM preparation was made from the maceration residue of the chert nodules to study the bacterial punctae in detail. Several rods whose surface was usually smooth were discovered from the maceration residue. The rods formed groups in which individual rods occurred one after another forming rows or twists (Figs. 7 C, D).
Rods with a punctate surface were rarities (Figs. $7 \mathrm{~A}$ and B). The rods average $2 \mu$ in diameter and $4 \mu$ in length, but the punctate form is $1.8 \mu$ in diameter and $7 \mu$ in length. Larger sheaths also found in the maceration residue probably correspond to forms described on the basis of examination under the optical microscope (Fig. 5). We did not, however, succeed in photographing intrasheathal dotted filaments.

The rods shown in Fig. 7 may be bacteria; the punctate type in particular (Fig. $7 \mathrm{~A}$ ) is likely to be a bacterial form. The rods adhering to each other and without surface patterns may be 

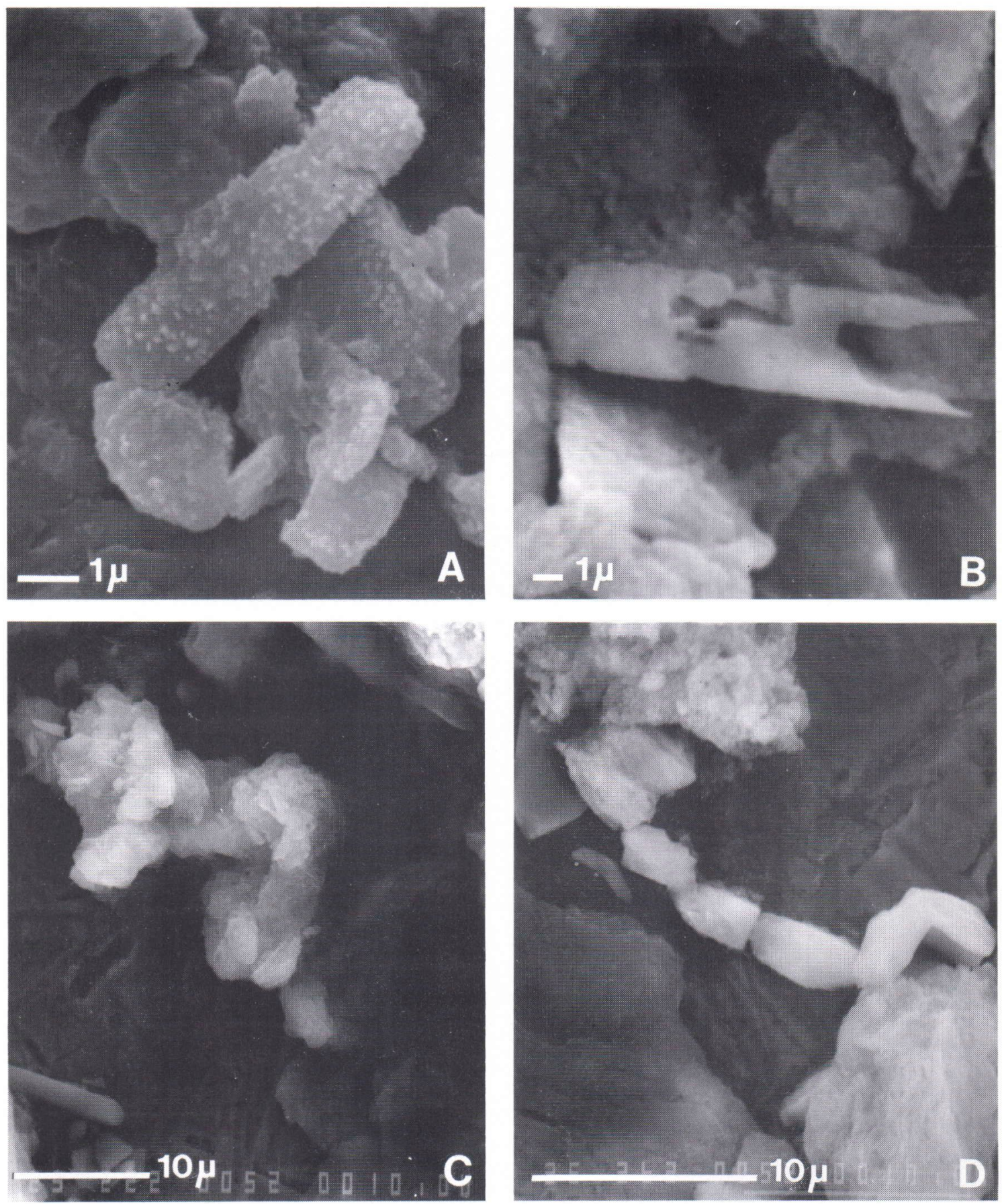

Figs. 7 A-D. SEM images of the bacterial forms in maceration residue. A and B probably show rod-like bacteria with punctate surface; D and E may exhibit bacterial filaments, but they may also be crystal aggregates. 
bacteria, but they could also be crystal accumulations.

Rods interpreted as bacteria have been described from Gunflint chert, age 1.6-2.0 × $10^{9}$ years (Schopf et al. 1965). The bacterial type of Gunflint resembles the Hyypiä type, but is only about half the size. Another bacterial type, Eoastrion simplex Barghoorn, also occurs at Gunflint. It has been compared with Metal-

\section{References}

Awramik, S. M.; Schopf, J. W. \& Walter, M. R., 1983. Filamentous fossil bacteria from the Archean of Western Australia. Precambrian Res. 20, 357-374.

Härme, M. \& Perttunen, V., 1963. Stromalite structures in Precambrian dolomite in Tervola, North Finland. Bull. Comm. Géol. Finlande 212, 79-82.

Hattori, K.; Krouse, H. R. \& Cambell, F. A., 1983. The start of sulfur oxidation in continental environments: about $2.2 \times 10^{9}$ years ago. Science 221, 549-551.

Kuznetsov, S. I.; Ivanov, M. V. \& Lyalikova, N. N., 1962. Vvedenie v geologicheskyu mikrobiologiju. Akad. Nauk SSSR Inst. Mikrobiologii, Moskva, 240 p.

La Rivière, J. W. M., 1966. The microbial sulfur cycle and some of its implications for the geochemistry of sulfur isotopes. Geol. Rundsch. 55, 568-582.

Meriläinen, K., 1980. On the stratigraphy of Karelian formations. In Silvennoinen, A. (ed.) Jatulian geology in the eastern part of the Baltic Shield. Proceedings of a FinnishSoviet Symposium, Finland, 1979, pp. 97-112.

Metzger, A. A. Th., 1924. Die jatulichen Bildungen von Suojärvi in Ostfinnland. Bull. Comm. Géol. Finlande 64, 86 p.

Nykänen, O., 1971a. Kallioperäkartan selitys, 4241 Kiihtelysvaara. English summary: Explanation to the map of rocks. Geological Map of Finland 1: 100 000, 68 p.

—, 1971b. On the Karelides in the Tohmajärvi area, Eastern Finland. Bull. Geol. Soc. Finland 43, 93-108.

Ojakangas, R. W., 1965. Petrography and sedimentation of logenium personatum Perfil'yev, a bacterium that oxidizes iron and manganese and which has been described from several lakes in Soviet Karelia (Kuznetsov et al. 1963).

Acknowledgements. We thank Assistant Professor Seppo Niemelä of the Microbiological Institute at the University of Helsinki for useful discussions and Ph. Lic. Anneli Uutela of the Geological Survey of Finland for the SEM images.

the Precambrian Jatulian quartzites of Finland. Bull. Comm. Géol. Finlande 214, 74 p.

Pekkarinen, L. J., 1979. The Karelian formations and their depositional basement in the Kiihtelysvaara-Värtsilä area, East Finland. Geol. Surv. Finland, Bull. 301, 141 p.

Pettijohn, E. J., 1975. Sedimentary rocks. 3nd ed. Harper and Row, New York, 628 p.

Schopf, J. W.; Barghoorn, E. S.; Maser, M. D. \& Gordon, R. O., 1965. Electron microscopy of fossil bacteria two billion years old, Science 149, 1365-1367.

Simonen, A., 1980. The Precambrian of Finland. Geol. Surv. Finland, Bull. 304, 58 p.

Stanier, R. Y.; Adelberg, E. A. \& Ingraham, J. L., 1976. General microbiology, 4th ed. Macmillan Press LTD, $871 \mathrm{p}$.

Timofeev, B. V., 1969. Sferomorfidy proterozoya. Akad. Nauk SSSR, Inst. Geologii in Geokhronologii Dokembriya, $146 \mathrm{p}$.

Tynni, R., 1971. Karjalaisten liuskeiden prekambrisista mikrofossiileista. Summary: Precambrian microfossils in Karelian schist. Geologi 23, 81-85.

Vologdin, A. G., 1970. Organic remains from Shungites of the Precambrian of Karelia. (Ostatki organizmov is shungitov dokembriya Karelii.) Dokl. Akad. Nauk SSSR, 193, 1163-1165.

Winkler, H. F., 1979. Petrogenesis of metamorphic rocks, 5th ed., Springer-Verlag Berlin, 348 p.

Manuscript received June 27, 1985. 